ceedings of the National Academy of Sciences of Belarus, Biological Series. 2010;2:75-80.

15. Zorova L. D., Popkov V. A., Plotnikov E. J., Silachev D. N., Pevzner I. B. [et al.] Roles of Mitochondrial Membrane Po- tential. Membrane and Cell Biology. 2017;34(6):93-100. https://doi.org/10.7868/S0233475517060020

\begin{abstract}
About authors:
Bykov Ilia Mikhaylovich, MD, PhD, Professor, Head of the Department of fundamental and clinical biochemistry; tel.: +79182125530; e-mail: ilya.bh@mail.ru

Berberidi Hristina Panaetovna, postgraduate student of the Department of fundamental and clinical biochemistry; tel.: +79189045555; e-mail: hristy@mail.ru

Popov Konstantin Andreevich, PhD, Assistant of the Department of fundamental and clinical biochemistry; tel.: +79288824941; e-mail: naftalin444@mail.ru

Ermakova Galina Alekseevna, PhD, Assistant of the Department psychiatry; tel.: +79182125530; e-mail: ilya.bh@mail.ru

Tsymbalyuk Igor Yuryevich, Laboratory Assistant of the Department of surgery № 2; tel.: +79284300769; e-mail: igor_ts@inbox.ru

Esaulenko Elena Evgenievna, MD, PhD, Professor of the Department of fundamental and clinical biochemistry;

tel.: +79184353523; e-mail: esaulenkoe@bk.ru

Denisova Yana Evgenievna, postgraduate student of the Department of fundamental and clinical biochemistry; tel.: +79182765890; e-mail: iana.denisova.1994@mail.ru

Azimov Erustam Adamovich, postgraduate student of the Department of fundamental and clinical biochemistry; tel.: +79183414969; e-mail: ilya.bh@mail.ru
\end{abstract}

\title{
MORPHOFUNCTIONAL CHANGES IN THE LIVER AND THE STATE OF THE RAT BLOOD COAGULATION SYSTEM IN DEVELOPMENT OF REPERFUSION SYNDROME
}

Pisarev A. A. ${ }^{1}$, Anisimova L. V. ${ }^{1}$, Fomochkina I. I. ${ }^{1}$, Kubyshkin A. V. ${ }^{1}$, Kuzichkin D. S. ${ }^{2}$, Shramko Ju. I. ${ }^{1}$, Kharchenko V. Z. ' ${ }^{1}$, Golubinskaya E. P. ${ }^{1}$

${ }^{1}$ Medical Academy named after S. I. Georgievsky of V. I. Vernadsky Crimean Federal University, Simferopol, Russian Federation

2 Institute of Biomedical Problems of RAS, Moscow, Russian Federation

\section{МОРФОФУНКЦИОНААЬНЫЕ ИЗМЕНЕНИЯ ПЕЧЕНИ И СОСТОЯНИЕ СИСТЕМЫ КОАГУАЯЦИИ КРОВИ КРЫСЫ ПРИ РАЗВИТИИ РЕПЕРФУЗИОННОГО СИНАРОМА}

А. А. Писарев ${ }^{1}$, А. В. Анисимова ', И. И. Фомочкина ${ }^{1}$, А. В. Кубышкин ${ }^{1}$, А. С. Кузичкин ${ }^{2}$, Ю. И. Шрамко ${ }^{1}$, В. 3. Харченко ${ }^{1}$, Е. П. Голубинская ${ }^{1}$

1 Мелицинская акалемия им. С. И. Георгиевского Крымского фелерального
университета им. В. И. ВернаАского, Симферополь, Российская ФеАерация
2 Институт меАико-биологических проблем РАН, Москва, Российская ФеАерация

Disseminated intravascular coagulation leads to the development of multiple organ failure syndromes with a mortality rate higher than $50 \%$. We examined the pathogenetic mechanisms of formation of systemic reperfusion syndrome in a rat model of reperfusion syndrome for 6,12 , and 24 hours. A total of 60 white Wistar rats, with a weight of 180-200 g, were studied. We found that morphological changes in the liver were manifested by formation of triggers for hepatocyte damage, including activation of apoptosis and initiation of pro-inflammatory damage pathways. These changes did not lead to severe alterations in functional activity of the liver. Disturbances in the blood coagulation system that developed with reperfusion syndrome with a potential threat of developing DIC were associated with increased consumption of coagulation factors. These disturbances in the blood coagulation system were also associated with inhibition of synthetic function of the liver to a lesser extent. 
В результате проведенных экспериментальных исследований по изучению патогенетических механизмов формирования системного реперфузионного синдрома в течение 6, 12 и 24 часов установлено, что морфологические изменения печени проявляются формированием пусковых механизмов повреждения гепатоцитов, включая активацию апоптоза и запуск провоспалительных путей повреждения. Эти изменения не приводят к выраженным нарушениям функциональной активности печени. Развивающиеся при реперфузионном синдроме выраженные нарушения в системе свертывания крови с потенциальной угрозой развития ДВС-синдрома в большей степени связаны с усилением потребления факторов свертывания и в меньшей мере с угнетением синтетической функции печени.

Ключевые слова: печень, свертывающая система крови, реперфузионный синдром, апоптоз, воспаление

For citation: Pisarev A. A., Anisimova L. V., Fomochkina I. I., Kubyshkin A. V., Kuzichkin D. S., Shramko Ju. I., Kharchenko V. Z., Golubinskaya E. P. MORPHOFUNCTIONAL CHANGES IN THE LIVER AND THE STATE OF THE RAT BLOOD COAGULATION SYSTEM IN DEVELOPMENT OF REPERFUSION SYNDROME. Medical News of North Caucasus. 2019;14(3):527-531. DOI - https://doi.org/10.14300/mnnc.2019.14130

Для цитирования: Писарев А. А., Анисимова Л. В., Фомочкина И. И., Кубышкин А. В., Кузичкин Д. С., Шрамко Ю. И., Харченко В. З., ГоЛУбИНскаЯ Е. П. МОРФОФУНКЦИОНАЛЬНЫЕ ИЗМЕНЕНИЯ ПЕЧЕНИ И СОСТОЯНИЕ СИСТЕМЫ КОАГУЛЯЦИИ КРОВИ КРЫСЫ ПРИ РАЗВИТИИ РЕПЕРФУЗИОННОГО СИНДРОМА. МедИцинСКИЙ вестник Северного Кавказа. 2019;14(3):527-531. DOI - https://doi.org/10.14300/mnnc.2019.14130

ALT - alanine transaminase

APL - antiplasmin

APTT - activated partial thromboplastin time

AST - aspartate transaminase

DIC - disseminated intravascular coagulation
GGT - gamma-glutamyl transpeptidase

INR - international normalized ratio

PG - plasminogen

RS - reperfusion syndrome
$\mathrm{T}$ he liver plays a fundamental role in direct and indirect regulation of almost all aspects of the hemostatic system and synthesizes the bulk of coagulation factors [1]. The compensatory abilities of the blood coagulation system noticeably weaken with liver pathology of various etiologies [2]. Depending on the situation, this leads to development of bleeding or thrombosis. Occurrence of hemorrhagic complications is a common clinical problem in patients not only with direct liver pathology, but also in extreme conditions of the body [3-5]. Moreover, liver damage during extreme conditions is a serious problem. Additionally, the condition of the blood coagulation system is considered essential for development of disseminated intravascular coagulation (DIC). DIC leads to development of multiple organ failure syndromes with a mortality rate higher than $50 \%$ [6-9].

Notably, some researchers have questioned development of DIC in a classical form [10, 11]. Therefore, the problem of consumption coagulopathy in critical conditions remains relevant $[11,12]$. The pathogenesis of DIC, including the relationship of morphofunctional changes in the liver with indicators of the hemocoagulation system, remains debatable. This issue needs to be solved by performing experimental studies of extreme conditions using the model of ischemia-reperfusion $[13,14]$ with the multiparameter assessment of liver function and coagulation status.

Therefore, this study aimed to determine the general patterns of morphofunctional changes in the liver and the blood coagulation system with the development of experimental reperfusion syndrome.

Material and Methods. A total of 60 white Wistar rats, with a weight of $180-200 \mathrm{~g}$, were studied. The rats were kept in identical standard conditions, which were required to create the groups. The V. I. Vernadsky Crimean Federal University, Medical Academy named after S. I. Georgievsky Ethics Committee approved the study protocol (protocol № 2, September 11, 2015).

The model of reperfusion syndrome (RS) was used to examine pathogenetic changes in the blood coagulation system, and nonspecific proteinases and their inhibitors. This model was created by applying rubber bands to both hind limbs of the rats at the level of the inguinal fold for 6 hours $[13,14]$. The width of the cross-clamping of the tissue was 2-3 $\mathrm{mm}$. An indication of a correct tourniquet was the absence of edema in the extremities and a pale appearance. Revascularization was performed simultaneously by cutting the bundles 6 hours after their restriction. Euthanasia of rats was performed under thiopental anesthesia by decapitation after 6 hours of ischemia, and within 6,12 , and 24 hours after reperfusion. A group of intact rats was used as a control.

Blood of rats was obtained by a single cardiopuncture of $4 \mathrm{ml}$ in disposable syringes. The blood was stabilized in a solution of $0.05 \mathrm{M}$ ethylenediaminetetraacetic acid and then centrifuged for 15 minutes at $5000 \times \mathrm{g}$.

Biochemical blood tests were performed using an automatic analyzer (Targa BT 3000; Biotechnica Instruments, Italy) with standard commercial kits (DiaSys Technologies SARL). We measured the following biochemical parameters: aspartate transaminase (AST), alanine transaminase (ALT), gamma-glutamyl transpeptidase (GGT), total protein, albumin, and glucose.

The following parameters were determined to evaluate the state of the coagulation system: international normalized ratio (INR), activated partial thromboplastin time (aPTT), soluble fibrin monomer complex (SFMC), plasminogen (PG), and antiplasmin (APL). Hemostatic parameters were measured on an automatic coagulometer (CA 1500; Sysmex, Japan) using standard commercial reagent kits (Siemens, Germany). Clotting methods were used to measure the INR and aPTT. Chromogenic methods were used to determine APL activity and PG concentrations. The content of the SFMC was assessed by the paracoagulatie manual method [3] using Technology-standard (Russia) kits.

A phased morphological study was carried out, including a standard histological study using hematoxylin and eosin staining and subsequent immunohistochemical (IHC) examination. Immunohistochemistry was performed on serial paraffin sections that were $4-\mu$ m thick (automatic rotational microtome, Leica RM 2255; Germany), and sections were then placed on adhesive slides (Leica Biosystems, UK). Antibodies for the apoptosis regulator BCL-2 protein (NCL-LBCL-2; Novocastra, 
Great Britain) at a dilution of $1: 100$ and a marker of Fas receptors (CD95; BD Biosciences, UK) at a dilution of 1:100 were used. The solution for dilution of primary antibodies was from Leica Biosystems. We also used monoclonal antibodies to the markers CD45 (X16/99; Leica Biosystems, UK), CD8 (4B11; Leica Biosystems, UK), CD68 (514H12; Leica Biosystems, UK), and CD56 (CD564; Leica Biosystems, UK). The Polymer Refine Detection System (Leica Biosystems, UK) was used. The reaction was carried out using an automated Bond Max IH staining system (Leica Biosystems Melbourne Pty, Australia). In each series, an additional response with negative and positive control tissues with the indicated antibodies was performed. Sections were viewed at a magnification of 400 in 10 fields of view. The Aperio CS2 drug scanner (Leica Biosystems, Germany) with Aperio ImageScope software was used for analysis. Viewing and taking digital photographs of micropreparations were carried out with an Olympus C $5050 Z$ digital camera mounted on an Olympus CX-41 microscope (Japan). Morphometric analysis of the obtained data was carried out using ImageJ licensed software.

All measurements were performed using measuring equipment that underwent metrological verification. Furthermore, auxiliary equipment was used that passed a certification based on the Center for the Collective Use of Scientific Equipment «Molecular Biology» of the Medical Academy named after S. I. Georgievsky of Crimean Federal University named after I. N. Vernadsky.

The data obtained during the study were processed using a certified MedStat computer processing package for working in the Windows environment. Values are shown as mean (M), an error of the mean $(\mathrm{m})$, and standard deviation. A comparison between groups was carried out using the Student's parametric criterion taking into account preliminary verification of data for normal distribution using the Shapiro - Wilk test. Results were considered statistically significant at $p<0.05$. The results of indicators of the hemostatic system are presented as relative differences with data in the control group shown as percentages.

Results and Discussion. Previous studies have shown that morphological changes in the liver in RS are characterized by different types of dystrophy, hemorheological disorders, and alterative-dystrophic processes of varying severity [4, 7]. In our study, in rats with development of 6 -hour limb ischemia, central venous congestion and petechial hemorrhage in liver tissue were observed. Additionally protein and partial hydropic dystrophy in hepatocytes were found [8].

In the current study, after a 6-hour reperfusion, more significant disturbances in hemorheology, such as centrilobular hyperemia, petechial hemorrhage, foci of hemorrhage in the central parts of lobules, and focal interstitial edema were found. We also observed hydropic degeneration and focal microvesicular fatty degeneration, mainly in the first zone of the acini.

Prolongation of reperfusion to 12 and 24 hours resulted in severe disorders of hemorheology, manifested by the development of centrilobular and sinusoidal capillaries, as well as by the presence of focal petechial hemorrhage in the center of the hepatic lobules. Additionally, there was extension of the lumen of central veins, plasma output, large foci of hemorrhage in the parenchyma, and stasis and sludge in the capillaries (Fig. 1). The increase in degenerative processes in hepatocytes was accompanied by the presence of diffuse intraplate edema, plates decomplexation, and monocellular and centrilobular necrosis. Focal, diffuse, and micro- and macrovesicular fatty dystrophy was observed in hepatocytes in all areas of acini. In the group of RS with a 24-hour reperfusion period, we found the diffuse extension of the Disse space with sinusoidal hyperemia, moderate diffuse leukocyte infiltration, and lymphocytes in the portal tracts and liver parenchyma. Furthermore, there were signs of central endotheliitis, as well as multiple foci of cholestasis.

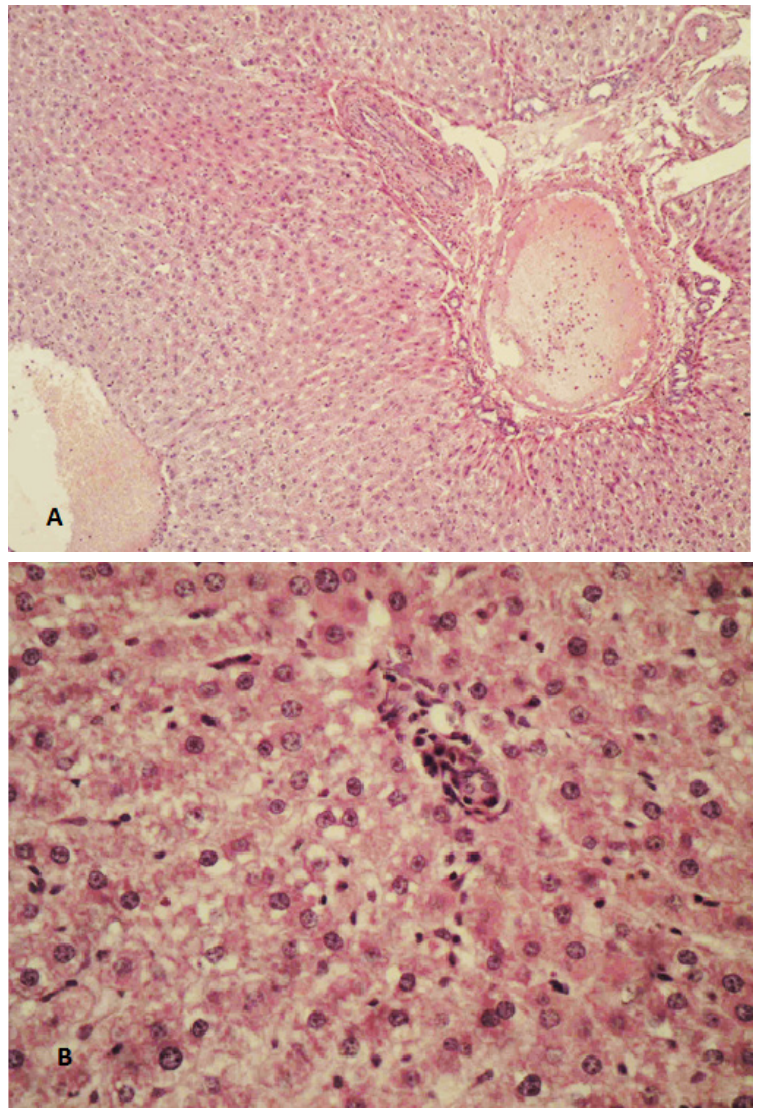

Fig. 1. (A) Rat liver tissue in the experimental group after 12 hours of reperfusion. Expansion and high density of vessels plasma output, perivascular edema, and focal microvesicular fatty degeneration can be seen. Hematoxylin and eosin stain; magnification, $\times 100$. (B) Rat liver tissue in the experimental group 24 hours after reperfusion. Macrovesicular fatty dystrophy and centrilobular necrosis can be seen. Hematoxylin and eosin stain; magnification, $\times 200$

Investigation of inflammatory and apoptotic markers in the development of RS using immunohistochemistry showed the following. Reaction with the Fas CD95 receptor marker showed biphasic activation of apoptosis with a gradual increase in the number of positively stained elements (hepatocytes and endothelial cells) in rats with RS compared with the control group. The presence of single CD95+ hepatocytes was observed, with a mean number of $5.01 \pm 0.61$ cells, in liver tissue in the control group. In rats with 6-hour ischemia, there was a higher than three-fold increase in the number of death receptor carrier cells. In rats with 6 -hour ischemia complicated by a similar time of reperfusion, an even more significant 17fold increase in the number of death receptor carrier cells was found, as shown by expression of endotheliocytes of sinusoidal veins and nearby hepatocytes. The peak of Fas-dependent apoptosis was observed in reperfusion at 12 hours compared with controls (Fig. 2).

In IHC, BCL-2 indicated short-term activation of apoptosis blockers in acute liver injury syndrome. This finding was probably protective in association with the simultaneous increase in CD95+ cell numbers. However, 
even in the group with 6 hours of reperfusion, there was a marked reduction in antiapoptotic factors compared with controls (Fig. 3). Additionally, along with activation of proapoptotic molecules and progression of necrobiotic changes, there was a significant increase in the number of CD68+ macrophages, CD56 in natural killer cells, CD8 in cytotoxic lymphocytes, and CD45 of the total leukocyte factor in tissue with maximally expressed quantitative indicators after 24 hours of reperfusion.
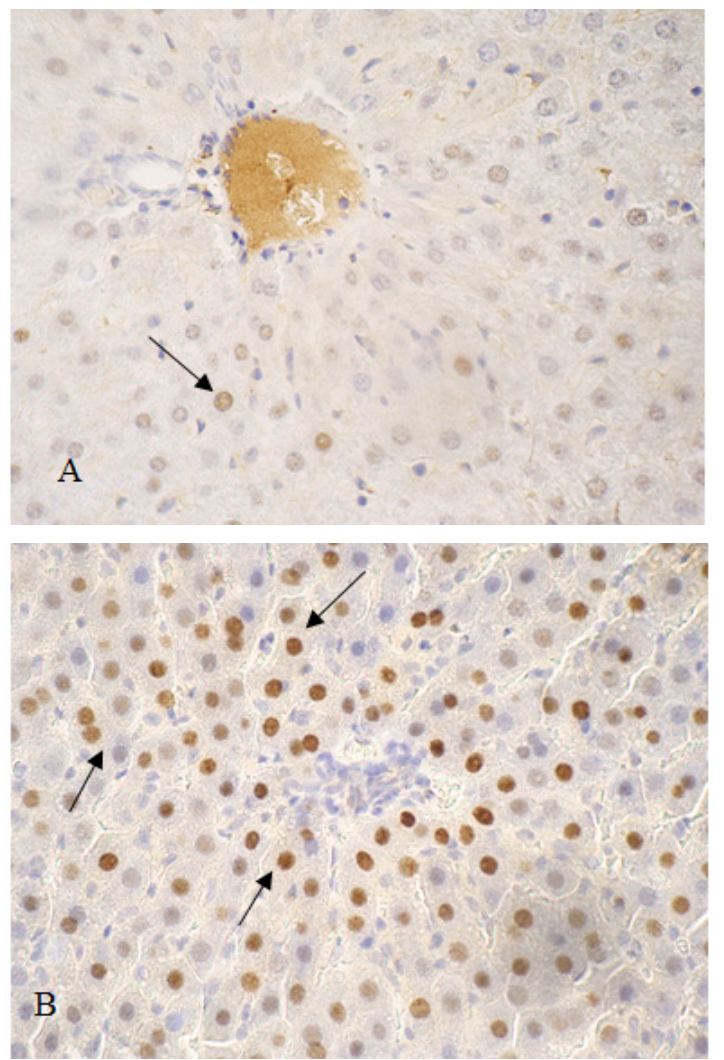

Fig. 2. Immunohistochemistry with the CD95 marker in the control $(A)$ and experimental $(B)$ groups with reperfusion of 12 hours. A positive nuclear reaction in hepatocytes can be seen. Magnification, $\times 20$

These results of IHC reactions and pathomorphological changes in hepatic parenchyma suggest that cross-molecular and cross-cellular interactive reactions occur in the development of RS in the liver. Changes in the early stages of RS lead to the induction of Fasdependent apoptosis of hepatocytes and endothelial cells. Subsequently, an increase in duration of RS leads to progression of other secondary disorders. This is actively caused by migration of macrophages and lymphocytes of which their cytotoxic effects cause necrotic damage of hepatocytes.

We also investigated the changes in biochemical blood parameters for characterizing the functional state of the liver. During the development of RS, we did not observe a decrease in the levels of proteins that are synthesized in the liver. Total protein and albumin levels were slightly decreased by 6 hours of reperfusion, but then returned to their original levels.

During ischemia and at early reperfusion, there were no changes in serum AST and ALT concentrations. At 24 hours of reperfusion, serum AST and ALT concentrations were significantly (both $\mathrm{p}<0.05$ ) higher compared with controls. This finding suggests that necrotic changes in the liver were not yet critical and did not lead to massive accumulation of intracellular proteins in the blood. However, gamma-glutamyl transpeptidase levels decreased with the development of reperfusion syndrome. Blood glucose levels were slightly reduced after 6 hours of reperfusion, but then remained at the level of control values after this time.
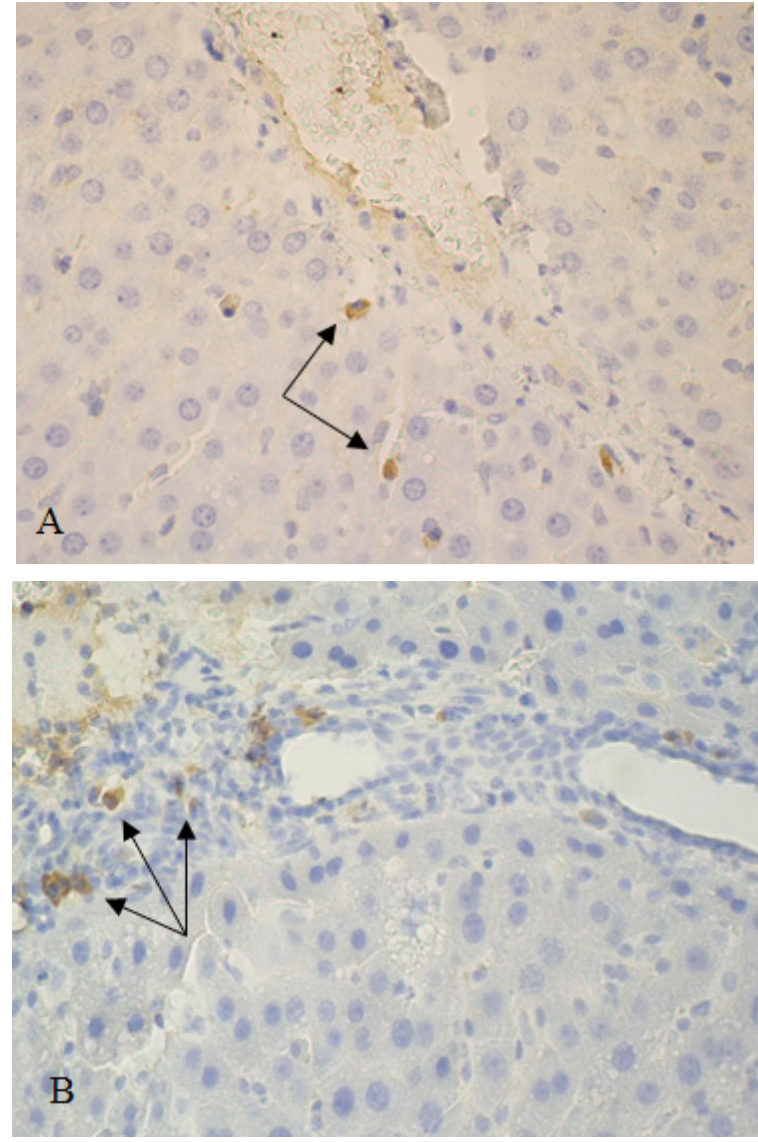

Fig. 3. Immunohistochemistry with the marker BCL-2 in the liver of rats in the control (A) and experimental (B) groups during reperfusion for 6 hours. A cytoplasmic positive response can be seen. Magnification, $\times 40$

In contrast, more significant $(p<0.01)$ changes were found in the study of rat hemostasis with the RS model. Six hours of ischemia did not cause significant changes in hemostasis, and only the INR was increased. However, there were obvious changes in external and internal clotting tests by the 6th hour of developing reperfusion injury. At this time, the INR value was significantly $(p<0.01)$ higher and the aPTT was prolonged by $170 \%$ compared with the control group.

We observed a significant decrease in the content of soluble fibrin monomer complexes by $62 \%$ compared with the control group. Additionally, blood plasminogen levels were increased, with a reduction in blood APL levels in rats. Prolongation of the aPTT indicated excessive consumption of blood coagulation factors (i.e., hypercoagulation). Hypercoagulation is associated with intensive formation of an active prothrombinase complex by the internal mechanism of hemocoagulation.

At 12 hours of RS, the increase in INR continued, and it was two-fold higher than control values. Additionally, at this time, the aPTT was further prolonged and was fivefold longer than control values. More intensive plasmininduced cleavage of peptide bonds in fibrin and fibrinogen was accompanied by accumulation of fibrin degradation products (fibrinogen), which were 1.2-fold higher than control levels. Two-fold higher INR levels characterized 
prolongation of reperfusion up to 24 hours, and a fivefold rise in the duration of the aPTT duration compared with controls. Stable high SFMC concentrations were also observed with reperfusion up to 24 hours.

Analysis of coagulation system dynamics showed significant differences in hemostasis system reactions at different time intervals of ischemia-reperfusion. In the short term, at 6-hours of reperfusion, there was activation of blood clotting factors with a predominance of hypercoagulation. This finding can be explained by systemic activation of plasma systems in response to acute stress damage. Prolongation of RS to 12-24 hours resulted in hypocoagulative changes in hemostatic parameters. This may have been associated with depletion of blood clotting factors and termination of their entry into systemic blood flow because of inhibition of liver function.

Conclusions. Our study indicates that morphological changes in the liver during the first day of development of RS involve stimulation of pro-inflammatory pathways of damage to hepatocytes, including activation of apoptosis. Disruption of the blood coagulation system is largely associated with increased consumption of coagulation factors, and to a lesser extent, with inhibition of the synthetic function of the liver.

Disclosures:

The authors declare no conflict of interest.

\section{Acknowledgments:}

The work was carried out within the framework of the academic mobility project «Development of research in the field of experimental medicine» of V. I. Vernadsky Crimea Federal University Development program. We thank Ellen Knapp, PhD, from Edanz Group (www.edanzediting.com/ac) for editing a draft of this manuscript.

\section{References}

1. Intagliata N. M., Davis J.-P. E., Caldwell S. H. Coagulation Pathways, Hemostasis, and Thrombosis in Liver Failure. Seminars in respiratory and critical care medicine. 2018;39(5):598-608 https://doi.org/10.1055/s-0038-1673658

2. Aithal G. P., Watkins P. B., Andrade R. J. Case definition and phenotype standardization in drug-induced liver injury. Clinical Pharmacology \& Therapeutics. 2011;89(6):806815. https://doi.org/10.1038/clpt.2011.58

3. Morozov Y. A., Mednikov R. V., Charnaya M. A. Hemostasis disorders and their diagnosis in liver pathology. Gemorragicheskie diatezy, trombozy, trombofilii. - Hemorrhagic diathesis, thrombosis, thrombophilia. 2014;(1):162171 .

4. Batyrova A. S., Bakanov M. I., Surkov A. N. Modern concepts of the hemostasis system in chronic liver diseases (literature review). Klinicheskaya laboratornaya diagnostika. - Clinical laboratory diagnosis. 2015;60(8):40-44. 5. Kurkina I. A., Maevskaya M. V., Ivashkin V. T. Hypercoagulation and thrombosis in patients with liver cirrhosis. Poliklinika. - Polyclinic. 2015;4(2):7-10.

6. Gando S., Levi M., Toh C. H. Disseminated intravascular coagulation. Nature Reviews Disease Primers. 2016;2:16031607. https://doi.org/10.1038/nrdp.2016.37

7. Cohen M. J., Call M., Nelson M., Calfee C. S., Esmon C. T. [et al.] Critical role of activated protein $C$ in early coagulopathy and later organ failure, infection and death in trauma patients. Annals of surgery. 2012;255(2):379-385. https://doi.org/10.1097/SLA.0b013e318235d9e6

8. Kubyshkin A. V., Pylayeva N. Yu., Fomochkina I. I., Pisarev A. A. Trauma, hemostasis and disseminated intra- vascular coagulation syndrome: pathogenic mechanisms of coagulation disorders. Klinicheskaya patofiziologiya. Clinical pathophysiology. 2016;22(4):104-117.

9. Litvitskii P. F. Pathology of the hemostatic system. Voprosy sovremennoy pediatrii. - Current Pediatrics. 2014;13(2):6576. https://doi.org/10.15690/vsp.v13i2.974

10. Thachil J. The Elusive Diagnosis of Disseminated Intravascular Coagulation: Does a Diagnosis of DIC Exist Anymore? Semin. Thromb. Hemost. 2019;45(1):100-107. https://doi.org/10.1055/s-0038-1677042

11. Yoshimura J., Yamakawa K., Kodate A., Kodate M., Fujimi S. Prognostic accuracy of different disseminated intravascular coagulation criteria in critically ill adult patients: a protocol for a systematic review and meta-analysis. BMJ Open. 2018;8(12):e024878.

https://doi.org/10.1136/bmjopen-2018-024878

12. Levi M. Toh C. H. Thachil J., Watson H. G. Guidelines for the diagnosis and management of disseminated intravascular coagulation. British Committee for Standards in Haematology. British journal of haematology. 2009;145(1):2433. https://doi.org/10.1111/j.1365-2141.2009.07600.x

13. Carden D. L., Granger D. N. Pathophysiology of ischemia-reperfusion injury. The Journal of Pathology. 2000; 190(3):255-266

https://doi.org/10.1002/(SICI)1096-9896(200002)190: 3<255::AID-PATH526>3.0.CO;2-6

14. Hughes S. F., Hendricks B. D., Edwards D. R., Bastawrous S. S., Roberts G. E. [et al.] Mild episodes of tourniquet-induced forearm ischemia-reperfusion injury results in leukocyte activation and changes in inflammatory and coagulation markers. Journal of inflammation. 2007;4:12. https://doi.org/10.1186/1476-9255-4-12

\footnotetext{
About authors:

Pisarev Anatolii Arkadevich, postgraduate student; e-mail: pisarev0812@icloud.com; ORCID - 0000-0002-9204-5198

Anisimova Lyudmila Vasilievna, PhD, Associate Professor of the Department of general and clinical pathophysiology; e-mail: anisanislv@mail.ru; ORCID - 0000-0001-9412-5071

Fomochkina Iryna Ivanovna, MD, DMSc, Professor of the Department of general and clinical pathophysiology; e-mail: fomochkina_i@mail.ru; ORCID - 0000-0003-3065-5748

Kubyshkin Anatoliy Vladimirovich, MD, DMSc, Professor of the Department of general and clinical pathophysiology, Vice-rector on scientific work; e-mail: kubyshkin_av@mail.ru; ORCID - 0000-0002-1309-4005

Kuzichkin Dmitry Sergeevich, PhD, Senior Researcher; e-mail: dsk1685@gmail.com

Shramko Juliana Ivanovna, PhD, Associate Professor of the Department of general and clinical pathophysiology; tel.: +79787529673; e-mail: julianashramko@rambler.ru; ORCID - 0000-0003-4946-7317

Kharchenko Vladimir Zakharovich, MD, DMSc, Professor of the Department of general and clinical pathophysiology; e-mail: prof.kharchenkovz@gmail.com; ORCID -0000-0001-6607-1141

Golubinskaya Elena Petrovna, PhD, Associate Professor of the Department of pathological anatomy with sectional course; e-mail: missive@mail.ru; ORCID -0000-0003-3917-924X
} 